\title{
Frequency of Osteoporosis in Patients with Coronary Heart Disease
}

\author{
Jasim Mohammed Taib Al-Hayali* , Abd Al-Razak Salim Mahdy ${ }^{\star *}$ \\ * Department. of Medicine,, College of Medicine, University of Mosul, Mosul. \\ ** Department of Medicine ,Al-shrqat Hospital , Mosul-Iraq \\ Correspondence: jasimalhayli@yahoo.com
}

(Ann Coll Med Mosul 2019; 41 (2):132-138).

Received: 17 ${ }^{\mathrm{TH}}$ Feb. 2019; Accepted: 29th Dec. 2019.

\section{ABSTRACT}

Objectives: To explore and discuss the possible relationship between coronary artery disease and osteoporosis in men and in postmenopausal women in comparison with healthy control.

Patients and methods: Fifty patients with ischemic heart diseases, with positive catheterization results whose ages range between $45-65$ years old were enrolled in the study and referred as Group A. Fifty aapparently healthy subjects, matched for $e$ with the patients group, were kept as control group and referred as Group B. We divided the patients understudy into two groups based on the mineral density they have; these groups are osteoporosis groupand normal bone mass group .

Results: The frequency of bone density by using Dexa (T-score) in studied subjects in Group A were normal $(\mathrm{T}$-score $=5.5$ to -0.9$)$ in $34(68 \%)$ subjects, osteopenia $(T \cdot$ score $=-1$ to -2.4$)$ in $11(22 \%)$ subjects, and osteoporosis (T-score $=-2.5)$ in $5(10 \%)$ subjects. For Group B, $32(64 \%)$ hainormal Dexa results, 17 (34\%) were osteopenic, and 1 (2\%) had osteoporosis.

The study has found that the relationship between the two groups was not statistically significant when tested by the chi square test.

Conclusion: There was no relationship between osteoporosis and cardiovascular diseases. Gender had no effects on osteoporosis.

Keywords : Osteoporosis, Coronary Heart Disease .

$$
\begin{aligned}
& \text { تواتر هشاشة العضام لاى المرضى المصابين بامراض التاجية }
\end{aligned}
$$

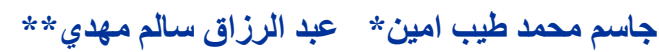

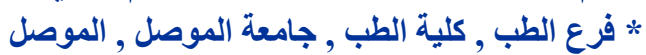

$$
\begin{aligned}
& \text { **:قسم الباطنية ، مستثفى الثرقاط ، الموصل-العراق المرل }
\end{aligned}
$$

الهـف من الدراسة: لاستكثاف ومناقثنة العلاقة المحتملة بين مرض الثريان التاجي و هثاثنة العظام لدى الرجال و النساء بعد

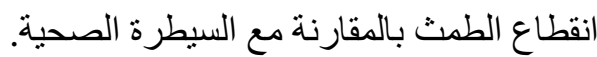

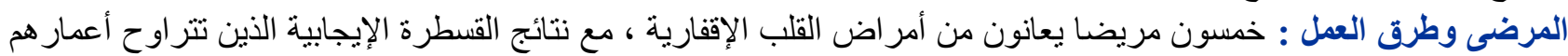

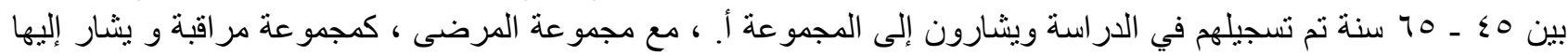

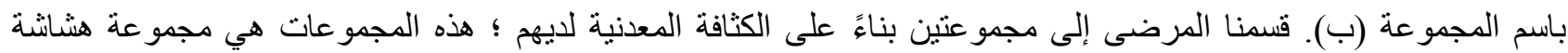
العظام ومجمو عة كتلة العظام الطبيعية. 


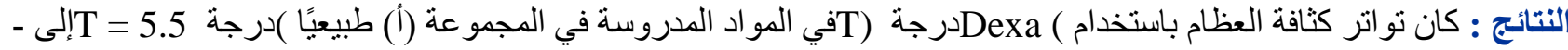

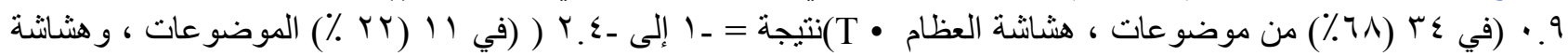

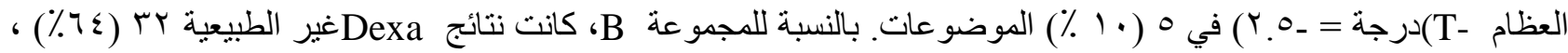

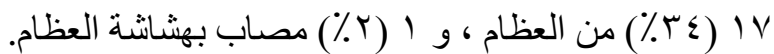

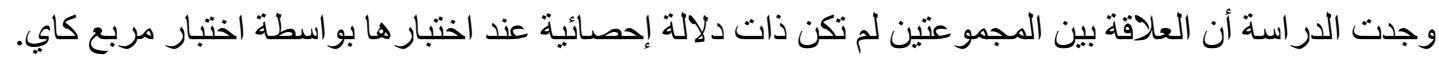
الاستنتاج: لم تكن هناك علاقة بين هشاثة العظام و أمر اض القلب و الأوعية الدموية. لم يكن للجنس أب تأثثير على هشانشة العظام. الكلمات المفتاحية : هشاشة العضام , امر اض الثرايين التاجية .

\section{INTRODUCTION}

oth Cardiovascular disease (CVD) and osteoporosis(OP) are normally related with the age of the patient and they both have essential impacts especially on personal satisfaction and wellbeing of people everywhere throughout the world. Despite the fact that these two diseases are commonly known as various elements and their concurrence was credited to free age-related procedures, gathering proof shows that there are comparable pathophysiological systems behind the two diseases.

Other diseases often occur with OP bone metabolism that have recently attracted the attention of scholars locally and internationally specially those who are specialized in cardiovascular diseases.

This disease is not only related to age but there are other causes and factors contributing to its occurrence as suggested by scholars; these reasons include dyslipidemia and diabetes ${ }^{1}$ as well as other known disorders like stress and inflammation ${ }^{2}$.

It has also been found that myocardial Ischemla, cardiovascular mortality, ardiovascular morbidity. and subclinical measures of atherosclerosis add to the occurrence of CVD as revealed by cross-sectional and longitudinal epidemiologic studies ${ }^{3}$.

Moreover, other studies have shown that there are other metabolic relationships between, osteoporosis and vascular calcification: estrogen deficiency ${ }^{4}$, vitamin $\mathrm{D}$ excess ${ }^{5}$ and lipid oxidation products ${ }^{6}$ as well as, osteoprotegerin, which is a protein that regulates osteoclast activity and proliferation ${ }^{7}$.

In spite of the above mentioned findings, the question that is to be raised is whether the age is the only factor that is to be taken into consideration as regard to this diseases, and if osteoporosis and coronary arterial disease are really related to each other or if they are independent processes. Thus more research is needed to find answers to the aforementioned questions in order to know how these two diseases are related to each other ${ }^{8}$.

\section{Aim of the Study}

The present study was aimed to seek the possible relationship between coronary artery disease and osteoporosis in men and in postmenopausal women in comparison with healthy control individuals.

\section{Subjects, Materials and Methods}

The current study was carried out during the period period between Nov. 011 and Jun 2012 in the Rheumatology outpatient department in Ebn Sena teaching hospital after taking the consent and approval of both the regional research committee of Mosul health dministration, and the scientific research committee of collage of medicine, university of Mosul, Mosul, Iraq,

Study design Case - control study Subjects

1) Patients group: Fifty patients with Ischemlc heart diseases, with

positive catheterization results whose ages range between 45 - 65 years old were enrolled in the study and referred as Group A.
A. Exclusion criteria.
1. Hyperthyroidism.
2. Steroid therapy for long period.
3. Alcoholism.
4. Chronic inflammatory diseases.
5. Patient under treatment for osteoporosis. 
2) Control group: Fifty apparently healthy subjects, matched for age.

with the patients group, were kept as control group and referred as Group B.

\section{Data collection}

In order to achieve the aims of the study, the data of this study is collected by interviews and a questionnaire. The researcher has directly interviewed the subjects and designed a questionnaire that includes personal information such as age, sex, body weight in ( $\mathrm{kg})$, height in $(\mathrm{m})$, BMI and biochemical profile (Appendix No.1).

\section{Instrumens}

1. Weight and height scale (secale) made in Germany. Body mass index (BMI) was calculated according to the equation:BMl=weight $(\mathrm{kg}) /$ height (m2).

2. Dual-Energy X-Ray Absorptiometry: Bone mineral density (BMD) was obtained at lumbar vertebrae in all subjects using dual energy $x$ ray absorptiometry (the name of the apparatus).

T-Score classification as following:

\begin{tabular}{ll}
\hline Normal & 5.5 to -0.9 \\
\hline Osteopenia & -1 to $>-2.5$ \\
\hline Osteoporosis & $<-2.5$ \\
\hline
\end{tabular}

\section{Statistical Analysis}

In order to be able to statistically analyze and test the results to find out the relationship between the parameters of the groups under study, we have used the following statistical means and tests : IBM SPSS Statistics Version 20.0 , Chi square and independent $\mathrm{t}$-test .

\section{RESULTS}

Fifty patients in Group A their mean age + SD were $52.90+5.33,28(56 \%)$ of

them were males and $22(44 \%)$ were females. Fifty patients in Group B their mean age+SD were $52.226 .36,19(38 \%)$ of them were males and $31(62 \%)$ were females. No significant differences between mean age for studied groups by applying independent t-test for two means for each group Table 1 , and also

There is no significant differences between both groups regarding gender by applying chi square test Table 2 .

Table1: The age of the studied groups.

\begin{tabular}{cccc}
\hline AGE & GROUP A & GROUP B & P- VALUE \\
\hline Mean+/- SD & $52.90+1-5.33$ & $52.22+1-6.36$ & \\
Minimum & 42 & 41 & 0.084 \\
\hline Maximum & 62 & 65 & \\
\hline
\end{tabular}

Independent t-test for two means was used.

Table 2 : The gender of the studied groups.

\begin{tabular}{|c|c|c|c|c|c|}
\hline \multirow{2}{*}{ Sex } & \multicolumn{2}{|c|}{ GROUP A } & \multicolumn{2}{|c|}{ GROUP B } & \multirow{2}{*}{ P-VALUE } \\
\hline & $\mathrm{N}$ & $\%$ & $\mathrm{~N}$ & $\%$ & \\
\hline MALE & 28 & $56 \%$ & 19 & $38 \%$ & \multirow{3}{*}{0.054} \\
\hline FEMALE & 22 & $44 \%$ & 31 & $62 \%$ & \\
\hline Total & 50 & $100 \%$, & 50 & $100 \%$ & \\
\hline
\end{tabular}

Chi-square test was used. 
The mean and standard deviation of Dexa results by using T- score for Group A were $-0.38+1.63$, and for Group B were $-0.35+1.28$. There was no significant differences ( $P$ value $=0.137$ ) between two groups by applying independant t-test Table 3 .

Table 3: Dexa (T-Score) Mean+SD results for studied groups.

\begin{tabular}{cccc}
\hline Bone desity by DEXA (T-Score) & GROUP A & GROUP B & P-VALUE \\
\hline Mean+/- SD & $-0.38+\mid-$ & $-0.35+/-$ & 0.137 \\
Minimum & 1.63 & 1.28 & -2.5 \\
\hline
\end{tabular}

Independent t-test for two means was used.

The frequency of bone density by using Dexa (T-score) in studied subjects in Group A were normal (Tscore $=5.5$ to -0.9$)$ in $34(68 \%)$ subjects, osteopenia $(T \cdot$ score $=-1$ to -2.4$)$ in 11 (22\%) subjects, and osteoporosis (T-score $=-2.5)$ in $5(10 \%)$ subjects. For Group B, $32(64 \%)$ hBfi normal Dexa results, $17(34 \%$,$) were osteopenic, and 1$ (2\%) had osteoporosis.

The chi square test $(P$ value $=0.067)$ has shown that the relationship between the groups was not statistically significant. Table 4 .

Table 4: Dexa (T-Score) frequency for studied groups.

\begin{tabular}{|c|c|c|c|c|c|}
\hline \multirow{2}{*}{$\begin{array}{l}\text { Bone density by Dexa (T- } \\
\text { Score) }\end{array}$} & \multicolumn{2}{|c|}{ Group A } & \multicolumn{2}{|c|}{ Group B } & \multirow{2}{*}{ p-value } \\
\hline & $N$ & $\%$ & $N$ & $\%$ & \\
\hline $\begin{array}{c}\text { Normal }(5.5 \text { to - } \\
0.9)\end{array}$ & 34 & $68 \%$ & 32 & $64 \%$ & \\
\hline $\begin{array}{l}\text { Osteopenia } \\
\text { (1to2.4) }\end{array}$ & 11 & $22 \%$ & 17 & $34 \%$ & 0.067 \\
\hline $\begin{array}{c}\text { Osteoporosis ( } \\
2.5 \text { ) }\end{array}$ & 5 & $10 \%$ & 1 & $2 \%$ & \\
\hline Total & 50 & $100 \%$ & 50 & $100 \%$ & \\
\hline
\end{tabular}

Chi-square test was used.

There was no effect of gender on Dexa results in both groups by using independent $t$ test for two means for each group. In Group A., the mean+SD of T-score in males were $-0.217+1.798$ and in females were $-0.595+1.388(P$ value $=0.588) \quad($ Table -5$)$. In GroupB, the mean $+S D$ of Tscore in males were $-0.631+$ 1.505 and in females were $-0.218+1.163 \quad(P$ value $=0.1) \quad$ Table 6 . 
Table 5: The effect of gender on the Dexa results in Group A

\begin{tabular}{|c|c|c|c|}
\hline Gender & NO & $\begin{array}{c}\text { T-score } \\
\text { MEAN +/-SD }\end{array}$ & P- Value \\
\hline Male & 29 & $\begin{array}{c}0.217+/- \\
1.798\end{array}$ & \\
\hline Female & 21 & $\begin{array}{c}0.595+/- \\
1.388\end{array}$ & \\
\hline
\end{tabular}

Independent t-test for two means was used.

Table 6: The effect of gender on the Dexa results in Group B

\begin{tabular}{|c|c|c|c|}
\hline Gender & NO & $\begin{array}{c}\text { T-score } \\
\text { MEAN +/-SD }\end{array}$ & P Value \\
\hline Male & 16 & $\begin{array}{c}0.631+/- \\
1.505\end{array}$ & \multirow{2}{*}{0.1} \\
\hline Female & 34 & $\begin{array}{c}0.218+/- \\
1.163\end{array}$ & \\
\hline
\end{tabular}

Independent t-te.st for two means was used.

\section{DISCUSSION}

Osteoporosis is one of the main diseases that cause health disorders universally. It is linked with fractures and consequently leads to death. Vascular calcification has been identified to be a disease that is not dependent risk factor for cardiovascular disease (CVD) ${ }^{9}$ and these two diseases concurrently happening to aging process . It has been demonstrated that there are similar regulatory mechanisms between the common characteristics of atherosclerotic plaques, calcification, and those seen in bone metabolism 10

The sort of the supposed relationship between osteoporosis and cardiovascular disease is still not clear enough. Conventionally it is known that they are not related and their development was due to processes which are not related to age ${ }^{11}$.
On the other hand, new studies have shown that the relationship between osteoporosis and cardiovascular ailment is not only due to the age factor, which is traditionally found in older populations. Thus there is a need to investigate the role of age factor in in younger populations. 11,12 .

Despite of high percent $(10 \%)$ of patients with cardiovascular problem had osteoporosis in comparison with control (2\%), statistically! there was no significant association between cardiovascular disease and osteoporosis epresented by low bone density. This finding was consistent with others reported by ,

This study corresponds with Ayoagi et al who conducted a study on Japanese - American women and found out that osteoporosis and coronary atherosclerosis are two unrelated processes where age is one of the influencing 
factors in postmenopausal women and in men as well $^{11,12}$.

Also there was no significant association between osteoporosis and sex in this study, although the present study showed that females had a low mean of bone density than mal - but still statistically not significant. This can be explained by the fact that women are physically less active than men, and the instances of overweight and obesity can be found more in women than men

as well as the sample size of this study was not enough to show this relation.

This can be explained by the fact that women are physically less active than men, and the instances of overweight and obesity can be found more in women than men

furthermore, the association between cardiovascular disease and osteoporosis has been observed almost only in women 13,14,15, raising further uncertainty

whether the two disease processes are truly linked.

Moreover, both osteoporosis and cardiovascular diseases increase with age ${ }^{11}$ and, in some studies, an association between bone mineral density (BMD) and cardiovascular diseases was lost once age was adjusted for ${ }^{16}$.

The present study showed normal mean level for T4 and TSH in both women and men regardless the result of $\mathrm{T}$-score and was statistically not significant in both males and females. This result inconsistent with other studies that showed a positive relation between osteoporosis in postmenopausal women.

\section{Conclusion \& Suggestion}

1.There was no relationship between osteoporosis and cardiovascular diseases.

2. Gender had no effects on osteoporosis.

3.More research is demanded to study this relationship both in men and women

with larger sample size and more diagnostic measurements for osteoporosis and atherosclerosis of coronary arteries.

\section{REFERENCES}

1.Demer, L., Vascular calcification and osteoporosis:inflammatory responses to oxidized lipids. Int. J. Epidemiol. 2002; 31, 737741.

2.Anagnostis, P., Karagiannis, A., Kakafika, A., Tziomalos, K.,Athyros, V., Mikhailidis, D. Atherosclerosis and osteoporosis: agedependent degenerative pro-cesses or related entities?Osteoporos. Int. 2009; 20, 197-207.

3.Jørgensen, L., Engstad, T., Jacobsen, B. Bone mineral density in acute stroke patients: low bone mineral density may predict first stroke in women. Stroke. 2001;32, 47-51.

4.Farhat, G., Strotmeyer, E., Newman, A., Sutton-Tyrrell, K., Bauer, D., Harris, T., Johnson, K., Taaffe, D., Cauley, J.Volumetric and areal bone mineral density measures are associated with cardiovascular disease in older men and women the health, aging, and body composition study. Calcif. Tissue Int. 2006; 79,102-111.

5.Anderson JL, et al. ACC/AHA guidelines for the management of patients with unstable angina/non-ST-Elevation myocardial infarction: a report of the American College of Cardiology/American Heart Association Task Force on Practice Guidelines. J Am CollCardiol. 2007 ; Aug 14 2007; 50:157.

6.Frye MA, Melton III LJ, Bryant SC, Fitzpatrick LA, Wahner HW, Schwartz 4244

J ClinEndocrinolMetab, September 2004, 89(9):4243- 4245.

7.Hirose K, Tomiyama H, Okazaki R, Arai $\mathrm{T}$, Koji Y, Zaydun G, Hori S, Yamashina A Increased pulse wave velocity associated with reduced calcaneal quantitative osteo-sono index: possible relationship between ath erosclerosis and osteopenia.

ClinEndocrinolMetab. 2003 ; 88:2573-2578.

8.Manolagas, S. From estrogen-centric to aging and oxidative stress: a revisedperspective of the pathogenesis of osteoporosis.Endocr. Rev. 2010; 31, 266-300

9.Christos E. Lampropoulos, IoannaPapaioannou \& David P. D'Cruz. Osteoporosis-a risk factor for cardiovascular disease?Nature Reviews Rheumatology 2012; 8: 587-598. 
10.Grayston JT, Kronmal RA, Jackson LA, Parisi AF, Muhlestein JB, Cohen JD, et al. Azithromycin for the secondary prevention of coronary events. N Engl J Med. Apr 21 2005;352(16):1637-45.

11. Aoyagi K, Ross PD, Orloff J, Davis JW, Katagiri $\mathrm{H}$, Wasnich RD. Low bone density is not associated with aortic calcification. Calcif Tissue Int. 2001; 69:20-24.

12.Bono CM, Einhorn TA. Overview of osteoporosis: pathophysiology and determinants of bone strength. Eur Spine J. Oct 2003;12Suppl 2:590-6.

13.Samelson EJ, Kiel DP, Broe KE, Zhang $Y$, Cupples LA, Hannan MT,Wilson PW, Levy D, Williams SA, Vaccarino V. Metacarpal cortical area and risk of coronary heart disease: the Framingham study. Am J Epidemiol. 2004; 159:589 -595.

14. Kiel DP, Kauppila LI, Cupples LA, Hannan MT, O'Donnell CJ,Wilson PW. Bone loss and the progression of abdominal aortic calcification over a 25 year period: the Framingham Heart Study. Calcif Tissue Int. 2001; 68:271-276

15.Van der Klift M, Pols HA, Hak AE, Witteman JC, Hofman A, de LaetCE. Bone mineral density and the risk of peripheral arterial disease: the Rotterdam Study. Calcif Tissue Int. 2002; 70:443- 449.49

16.Vogt MT, San Valentin R, Forrest KY, Nevitt MC, Cauley JA. Bone mineral density and aortic calcification: the study of osteoporotic fractures. J Am GeriatrSoc. 1997; 45:140 -145. 